\title{
PELATIHAN TEKNOLOGI PENGOLAHAN ES KRIM DENGAN PENSTABIL PORANG DI DESA GUMANTAR KECAMATAN KAYANGAN KABUPATEN LOMBOK UTARA
}

\author{
Rucitra widyasari ${ }^{\left.{ }^{*}\right)}$, Zainuri $^{1}$, Yeni Sulastri ${ }^{1}$, Dewa Nyoman Adi Paramartha ${ }^{1}$ \\ ${ }^{1}$ Program Studi Ilmu dan Teknologi Pangan, Fakultas Teknologi Pangan dan Agroindustri, \\ Universitas Mataram \\ ${ }^{*}$ Email : rucitrawidyasari@unram.ac.id
}

Diterima 24 Agustus 2020 / Disetujui 22 November 2020

\begin{abstract}
ABSTRAK
Porang adalah salah satu hasil pertanian di Kabupaten Lombok Utara yang saat ini sedang digalakkan pemerintah untuk menjadi salah satu primadona hasil pertanian di wilayah tersebut. Salah satu kandungan dalam porang yang banyak digunakan adalah glukomannan yang merupakan salah satu alternatif penstabil alami untuk aneka bahan pangan. Salah satunya adalah dalam pembuatan es krim. Berdasarkan hasil penelitian (Sulastri dkk, 2017) diketahui bahwa perlakuan terbaik adalah penggunaan penstabil porang dengan konsentrasi $0,5 \%$ dalam pembuatan es krim buah naga merah. Perlakuan tersebut mampu menyamai kemampuan CMC sebagai penstabil es krim. Sedangkan buah merah digunakan sebagai bahan baku es krim karena dengan warna yang menarik serta kaya akan nutrisi seperti vitamin $A, C$ dan $E$, protein, serat serta sumber mineral, seperti kalsium, fosfor dan magnesium (Cahyono, 2009). Kegiatan ini bertujuan untuk memberikan pengetahuan dan memberdayakan masyarakat desa Gumantar untuk dapat menggunakan sumber daya alam yang ada hingga bernilai ekonomi yang tinggi salah satunya adalah umbi porang. Petani porang diberikan pelatihan teknologi pengolahan porang sebagai penstabil es krim dengan menerapkan cara penanganan pangan yang baik (Good Handling Practices atau GHP) dan cara pengolahan pangan yang baik (Good Manufacturing Practices atau GMP.
\end{abstract}

Kata kunci: es krim, porang, stabilizer

\begin{abstract}
Porang is one of the agricultural products in North Lombok Regency which is currently being promoted by the government to become one of the prima donna of agricultural products in the region. One of the ingredients in porang that is widely used is glucomannan, which is an alternative natural stabilizer for various food ingredients. One of them is in making ice cream. Based on the research results (Sulastri et al., 2017) it is known that the best treatment is the use of porang stabilizers with a concentration of $0.5 \%$ in making red dragon fruit ice cream. This treatment is able to match the ability of $C M C$ as an ice cream stabilizer. Meanwhile, red fruit is used as raw material for ice cream because it is attractive in color and rich in nutrients such as vitamins $A, C$ and $E$, protein, fiber and mineral sources, such as calcium, phosphorus and magnesium (Cahyono, 2009). This activity aims to provide knowledge and empower the people of Gumantar village to be able to use existing natural resources of high economic value, one of which is the porang tuber. Porang farmers are given training in porang processing technology as an ice cream stabilizer by applying good food handling practices (Good Handling Practices or GHP) and good food processing methods (Good Manufacturing Practices or GMP).
\end{abstract}




\section{PENDAHULUAN}

Porang (Amorphophallus muelleri Blume) adalah tanaman umbi-umbian yang banyak dijumpai di wilayah Indonesia seperti Pulau Sumatera, Jawa, Sulawesi, Bali, Madura, Nusa Tenggara Barat dan Nusa Tenggara Timur (Jansen et al., 1996). Porang merupakan tanaman yang potensial untuk dikembangkan sebagai komoditi ekspor karena beberapa negara membutuhkan tanaman ini sebagai bahan makanan maupun bahan industri. Indonesia mengekspor porang dalam bentuk gaplek atau tepung ke Jepang, Australia, Srilanka, Malaysia, Korea, Selandia Baru, Pakistan, Inggris dan Italia. Permintaan porang dalam bentuk segar hingga sebagai bentuk produksi olahan terus meningkat. Sebagai contoh, produksi porang di Jawa Timur tahun 2009 baru mencapai 600 - 1000 ton chip kering sedangkan kebutuhan industri sekitar 3.400 ton chip kering (Wijanarko, 2009). Kebutuhan ini belum dapat dipenuhi karena di Indonesia porang belum di budidayakan secara intensif dan masih sangat tergantung pada potensi alam, luas penanaman yang masih terbatas dan belum adanya pedoman budidaya yang lengkap (Sumarwoto, 2004).

Umbi porang adalah hasil pertanian yang mempunyai nilai ekonomi tinggi karena dapat menghasilkan glukomanan yang dapat dimanfaatkan dalam industri sebagai komponen pangan dan farmasi. Umbi segar yang dipanen bersifat musiman, kamba, dan mudah rusak karena kandungan air relatif tinggi (75-87\%). Selama ini penanganan pascapanen umbi iles-iles mengalami susut mencapai $20-40 \%$ karena terbatasnya teknik dan fasilitas penanganan yang meliputi proses pencucian, pengirisan, pengeringan, pengemasan dan penyimpanan (Dwiyono et al., 2014). Davies et al. (2008) dan Udoh (2009) menyatakan bahwa penggunaan mesin, fasilitas penyimpanan dan peralatan pascapanen yang terdiri atas alat pengering, penggiling, pengupas kulit yang berbeda berpengaruh terhadap produktivitas produk pertanian. Penggunaan teknologi dan manajemen yang baik termasuk rantai pasok bahan baku umbi pada proses pascapanen dapat meningkatkan produktivitas produk pertanian dibandingkan penggunaan alat rumah tangga yang bersifat konvensional.

Salah satu potensi yang dapat dikembangkan dalam pengolahan porang yaitu produk chips dan turunannya berupa tepung porang. Tepung porang penerapannya sama dengan tepung dari bahan baku lainnya, hanya saja dengan adanya asam oksalat sedikit menyulitkan petani untuk mengolahnya, sehingga diperlukan teknologi sederhana untuk dapat memaksimalkan kadar glukomanan dari pengolahan lanjut chips porang tersebut. Pengabdian ini selain mengenalkan teknologi pengolahan tepung porang sebagai penstabil alternatif pada bahan pangan juga diharapkan dapat menyadarkan masyarakat khususnya petani akan potensi dari porang ini.

\section{METODE KEGIATAN}

\section{Pendekatan pemecahan masalah} mitra melalui sosialisasi pemanfaatan teknologi tepat guna merupakan salah satu cara yang dapat dilakukan untuk meningkatkan pengetahuan mitra diwilayah sasaran. Metode ini cukup efektif untuk memotivasi agar mampu menggunakan potensi dan kemampuan yang dimilikinya dalam mengelola 
komoditi lokal khususnya umbi porang sehingga memiliki nilai guna yang lebih tinggi. Sasaran yang akan diberikan pengetahuan adalah kelompok tani di Desa Gumantar, Kecamatan Kayangan, Kabupaten Lombok Utara. Serangkaian tahapan akan dilakukan meliputi penyebarluasan informasi, perubahan perilaku, pemberdayaan masyarakat sebagai upaya untuk meningkatkan produktivitas, efisiensi usaha, dan pendapatan. Dalam pelaksanaan kegiatan ini ada beberapa hal yang harus diperhatikan yaitu teknologi yang diberikan ke mitra berupa teknologi sederhana sehingga mudah diikuti, keterlibatan mitra secara aktif dari awal sampai akhir kegiatan, serta dukungan yang memadai dari pemerintah daerah setempat.

Metode yang akan dikembangkan dalam pelaksanaan pengabdian ini adalah dengan menerapkan metode penyuluhan teknologi pascapanen dan demonstrasi meliputi:

1. Penyuluhan

Penyuluhan dalam basis pertanian atau teknologi pangan merupakan suatu cara penyampaian melalui materi kepada masyarakat dalam layanan pendidikan untuk melatih dan mempengaruhi seseorang agar menerapkan praktek maju dalam teknologi pascapanen dan pengolahannya. Kegiatan penyuluhan ini terjadi proses ceramah, diskusi dan tanya jawab tentang keuntungan serta langkah-langkah yang harus dilaksanakan dalam penerapan pascapanen. Penyuluhan teknologi tepat guna mengenai proses

\begin{abstract}
pengolahan es krim dengan memanfaatkan porang sebagai bahan penstabil. Kegiatan ini diharapkan mampu mendorong tumbuhkembangnya kegiatan inovatif di masyarakat, khususnya teknologi tepat guna yang sesuai dengan kebutuhan masyarakat, dapat menjawab permasalahan masyarakat, tidak merusak lingkungan, dan dapat dimanfaatkan oleh masyarakat secara mudah serta menghasilkan nilai tambah dari aspek ekonomi dan aspek lingkungan hidup.
\end{abstract}

\section{Demonstrasi}

Demonstrasi merupakan metode penyuluhan secara pembuktian secara nyata berupa contoh yang dapat dilihat dan diamati sendiri. Demonstrasi dilakukan untuk meningkatkan keterampilan para kelompok tani mitra dalam menerapkan teknik pascapanen dan pengolahan porang yang baik dan benar.

\section{HASIL DAN PEMBAHASAN}

Kegiatan Program Pengabdian Masyarakat dengan tema "Pelatihan Teknologi Pengolahan Es Krim dengan Penstabil Porang di Desa Gumantar Kecamatan Kayangan Kabupaten Lombok Utara" telah dilaksanakan pada bulan Oktober 2020 dengan melibatkan partisipasi warga dan perangkat Desa Gumantar. Pengabdian ini dilaksanakan sebagai upaya pengenalan tentang pengembangan atau optimalisasi teknologi pengolahan umbi porang bagi petani atau masyarakat Desa Gumantar, Kecamatan Kayangan, Kabupaten Lombok Utara. 


\section{a. Penyampaian Materi Tentang \\ Pengolahan Es Krim dengan Penstabil Tepung Porang}

Petani dan masyarakat Desa Gumantar diberikan pengetahuan mengenai potensi porang meliputi konsep pengolahan pangan yang baik dan pengolahan umbi porang. Dalam mengolah produk pangan perlu memperhatikan pengolahan pangan yang baik dari segi faktor sanitasi dan higienitasnya. Pekerja atau karyawan yang mengolah bahan pangan harus sehat jasmani dan rohani serta mengerti tentang kesehatan. Tempat pengolahan pangan dan alat yang digunakan harus dalam keadaan bersih, bahan yang digunakan juga terlebih dahulu dicuci bersih dan juga sebaiknya membersihkan tangan sebelum mengolah makanan atau produk.

Pengolahan disebut dengan pengolahan sekunder yaitu tindakan yang mengubah hasil pertanian kekondisi lain atau bentuk lain dengan tujuan lebih tahan lama (awet), mencegah perubahan yang tidak diinginkan atau untuk penggunaan lainnya. Umbi porang dapat diolah menjadi bahan pangan, sehingga memanfaatkan umbi porang merupakan salah satu diversifikasi pangan. Selain itu, umbi porang dapat digunakan sebagai bahan baku kosmetik, obat-obatan dan bahan baku industri.

roduk antara umbi porang yaitu tepung porang, dimana tepung porang dapat diolah lebih lanjut menjadi penstabil dalam es krim. Hasil penelitian tim tahun 2018 diperoleh bahwa penambahan tepung porang sebanyak 0,1\% menghasilkan es krim dengan karakteristik fisikokimia yang mampu menyamai penstabil komersial seperti CMC dan gelatin. Tim pengabdian menyiapakn sampel es krim yang telah dibuat dilaboratorium sehingga dapat dicicipi oleh masyarakat Desa Gumantar (Gambar 1).

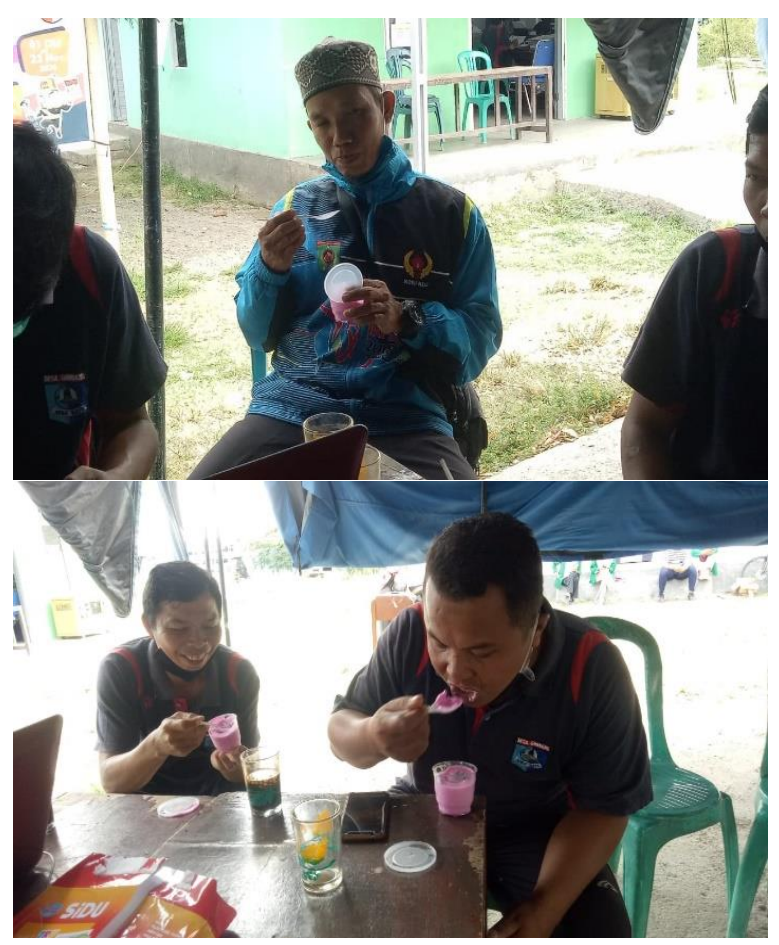

Gambar 1. Masyarakat desa Gumantar mencicipi es krim dengan penstabil tepung porang

\section{b. Diskusi}

Kegiatan diakhiri dengan diskusi ringan bersama warga. Pertanyaan disampaikan oleh warga sebagai bentuk antusias warga dalam menangkap materi yang disampaikan. Warga antusias untuk meningkatkan budidaya porang diwilayahnya karena mengetahui prospek porang sangat potensial baik sebagai produk antara maupun produk olahan. 


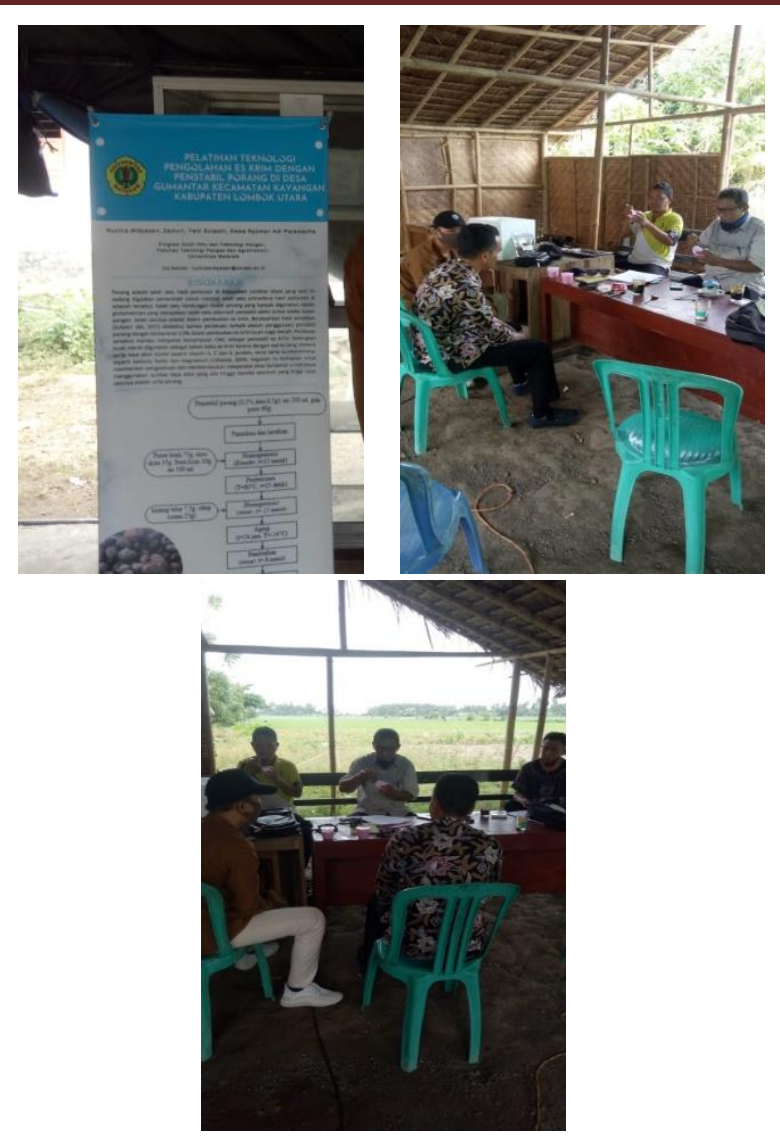

Gambar 2. Diskusi

\section{KESIMPULAN DAN SARAN}

\section{A. Kesimpulan}

Kegiatan pengabdian tentang teknologi pengolahan porang sebagai pentabil dalam es krim berjalan dengan lancar. Masyarakat Desa Gumantar, Kecamatan Kayangan, Kabupaten Lombok Utara antusias dalam mengikuti kegiatan dan bersemangat untuk menerapkan dalam kehidupan sehari-hari. Kegiatan ini perlu dilakukan karena dibutuhkan oleh petani porang atau masyarakat sebagai informasi dalam pentingnya penerapan cara pengolahan pangan yang baik dan teknologi pengolahan es krim dengan penstabil porang sebagai usaha dalam pemanfaatan optimal pengembangan bisnis umbi porang dan untuk jangka panjang, Pengetahuan yang diberikan dalam kegiatan sosialisai ini diharapkan mampu meningkatkan informasi dan pendapatan masyarakat sebagai pemulihan kegiatan ekonomi masyarakat.

\section{B. Saran}

Kegiatan pengabdian sejenis perlu dilakukan di Desa sekitar Kabupaten Lombok Utara Lainnya. Secara khusus pemerintah, melalui dinas-dinas terkait, diharapkan lebih banyak berperan dalam kaitan ini, agar banyak masyarakat yang tahu tentang manfaat dan nilai ekonomi dari tanaman porang ini untuk mengembangkan dan mengelola umbi porang secara optimalisasi yang dapat memenuhi kebutuhan pangsa pasar.

\section{DAFTAR PUSTAKA}

Cahyono, B. 2009. Buku Terlengkap Sukses Bertanam Buah Naga. Pustaka Mina, Jakarta.

Davies RM, Olatunji MO, dan Burubai W. 2008. a Survey of Cassava Machinery in Oyo State. World J. Agri Sci. 4(3): 337-340.

Dwiyono, K., Titi, C. S., Ono S. dan Liesbetini H. 2014. Penanganan Pascapanen Umbi lles-lles (Amorphophallus muelleri Blume) Studi Kasus di Madiun, Jawa Timur. J. Teknologi Industri Pertanian. 24 (3):179-188.

Jansen, PCM, Wilk CVD dan Hetterscheid WLA. 1996. Prosea: Plant Resources of South-East Asia. 9: 45-50.

Sulastri, Yeni, Dkk. 2017. Pengaruh Penambahan Berbagai Stabilizer Alami Untuk Peningkatan Mutu Es Krim Buah Naga ( Hylocereus 
Polyrhizus Sp.). jurnal profood. http://profood.unram.ac.id/index .php/profood/article/view/74 [diakses 19 januari 2020].

Sundari, Yusra A.H dan Nurliza. 2015. Peran Penyuluh Pertanian Terhadap Peningkatan Produksi Usahatani di Kabupaten Pontianak. J. Social Economic of Agriculture. 4 (1) : 26-3.

Sumarwoto. 2004. Pengaruh pemberian kapur dan ukuran bulbil terhadap pertumbuhan porang (Amorphophallus muelleri Blume) pada tanah ber-Al Tinggi. Jurnal Ilmu Pertanian.11(2): 45- 53.

Udoh, A.J. 2009. Adoption of Postharvest Crop Processing Machines for Increased Cassava and Maize
Production: a Food Security Measure for Poor Income Farmers in Rural Nigeria. Indian Re Ex Edu. 9(3): 78-82.

Widyasari, R., Sulastri, Y., Nofrida, R., Zaini, MA., Nasrullah, A., dan Zainuri. 2018. Pemanfaatan Tepung Umbi Minor Sebagai Alternatif Stabilizer Alami Untuk Meningkatkan Mutu Fisik Dan Inderawi Es Krim Buah Naga (Hylocereus polyrhizus sp.). Pro Food 4(1): 268-276.

Widjanarko, S.B. 2009. Prospek Pengembangan Porang dikawasan Hutan Jawa Timur.http://simonbwidjanarko. wordpress.com. Diakses 10 Januari 2020. 